\title{
Evaluation of Electrolytes Disturbances in Iraqi Chronic Myeloid Leukemia Patients treated with Nilotinib with Monitoring of Response by FISH Study
}

\author{
Bushra F. Hasan* Bassam F. Matti** \\ Rusul Y. Hameed*
}

Received 26, February, 2014

Accepted 16, March, 2014

\begin{abstract}
:
Chronic myeloid leukemia (CML) is a myeloproliferative disorder characterized by the presence Philadelphia chromosome $(\mathrm{Ph})$ which was created by a reciprocal translocation between chromosomes 9 and 22 (t [9;22] [q34;q11]. The approval of the $2^{\text {nd }}$ generation TKI ( Nilotinib) takes the treatment of CML patients into new erea with more efficiency and mild to moderate adverse effects. This study was aimed at evaluation of molecular cytogenetic response by (FISH) for Nilotinib in Iraqi patients with assessment for electrolytes disturbances of Nilotinb by measuring a panel of electrolyte $\left(\mathrm{Na}^{+}, \mathrm{K}^{+}, \mathrm{Ca}^{++}, \mathrm{PO}_{4}^{---}\right.$and $\left.\mathrm{Mg}^{++}\right)$, where thirty Iraqi patients with CML who have resistance or no response to Imatinib treatment, attending to Baghdad Teaching Hospital/Hematology Department, have been submitted to this study. Blood samples have been taken pre and post starting treatment with Nilotinib, FISH study was done only for CML patients, while 30 normal healthy control volunteers submitted to the same panel of electrolytes measurements $\left(\mathrm{Na}^{+}, \mathrm{K}^{+}, \mathrm{Ca}^{++}, \mathrm{PO}_{4}^{---}\right.$and $\left.\mathrm{Mg}^{++}\right)$in addition to pre and post treatment Nilotinib patients.

The results show out of 30 patients (17) males and (13) females with male to female ratio 1.3:1, FISH results for patients (pre and post) treatment mean \pm SD were $(58.7 \% \pm 26.2 \%$ and $45.7 \% \pm 29.9 \%)$ obviously significant with good cytogenetic response in resistance CML for Imatinib. Sodium levels in mmol/L pre, post treatment and control mean \pm SD were $(139.2 \pm 6.9,142.4 \pm 9.2$ and 140.4 \pm 2.52$)$ respectively, with no significant difference between each other with $\mathrm{P}$ value $>0.05$ in all comparisons. Potassium levels mean $\pm \mathrm{SD}$ in $\mathrm{mmol} / \mathrm{L}$ results for patients (pre, post) and control were $(4.6 \pm 0.69,4.3 \pm 0.68$ and $4.46 \pm 0.76)$ respectively, with no significant difference between each other with $\mathrm{P}$ value $>0.05$ in all comparisons. Calcium levels in $\mathrm{mg} / \mathrm{dL}$ results for patients (pre, post) and control as mean \pm SD were $(8.68 \pm 1.68$, $8.1 \pm 1.72$ and 9.12 \pm 0.38 ) respectively with no significant differences except between post treatment and control group with $\mathrm{P}$ value $>0.05$ in all comparisons. Phosphate levels in $\mathrm{mg} / \mathrm{dL}$ results for patients (pre, post) and control as mean $\pm \mathrm{SD}$ were $(2.5 \pm 0.84,2.95 \pm 1.04$ and $3.4 \pm 0.49)$ respectively with significant difference with $P$ value $<0.05$ in all comparisons. Magnesium levels in $\mathrm{mg} / \mathrm{dL}$ results for patients pre, post and control as mean \pm SD were $(1.93 \pm 0.34,2.06 \pm 0.44$ and $2.1 \pm 0.34)$ respectively with no significant difference between each other with $\mathrm{P}$ value $>0.05$ in all comparisons. This study sheds a light on the molecular cytogenetic response for CML patients who have already resistance to Imatinib and Nilotinib that has much more potent effect as approved by studies and this study has used FISH technique. This study emphasizes on the importance of evaluation of electrolyte panel for CML patients before starting Nilotinib study taking in to consideration if these patients are

*Department of Chemistry College of Science for Women, University of Baghdad.

**Consultant hematologist, Baghdad Teaching Hospital, Medical.
\end{abstract}


already receiving Imatinib which can also affect bone metabolism and calcium and phosphate levels.

\section{Key words: Chronic myeloid leukemia(CML), Fluorescent in situ hybridization(FISH)}

\section{Introduction:}

Chronic myeloid leukemia (CML) is a myeloproliferative disorder that is a consequence of an acquired mutation affecting hematopoietic stem cells. This mutation results in a balanced translocation between chromosomes 9 and 22, initially identified in 1960, and termed the $\mathrm{Ph}$ chromosome [t(9;22)(q34;q11)][1].

Chronic myeloid leukemia occurs more frequently in adults than in children. It occurs at roughly the same frequency in countries around the world and is no more common in one ethnic or racial group than in any other. The annual incidence rate is 1.6 cases per 100,000 adults (approximately 5000 new cases per year in the United States), with a male-to-female ratio of 1.4 to 1[2]. The median age at diagnosis is approximately 55 years, with less than $10 \%$ of patients under the age of 20 years[3].

CML normally progresses through three clinically recognized phases about $90 \%$ of patients are diagnosed during the typically indolent chronic phase (CP), which is followed by an accelerated phase (AP) and a terminal blastic phase (BP), $20-25 \%$ of patients progress directly from $\mathrm{CP}$ to $\mathrm{BP}$ and the time course for progression can be extremely varied [4]. In all patients with chronic phase CML, the disease has the potential to evolve into a more aggressive, more symptomatic, and troublesome phase, which is poorly responsive to the therapy that formerly controlled the chronic phase. The failure of therapy to restore or maintain near-normal red cell and white cell counts, increased spleen size, increased numbers of marrow blasts and blood basophils, loss of the sense of well-being, and appearance of extramedullary tumors are the most consistent clinical hallmarks of the metamorphosis of the chronic to the accelerated phase of CML[5,6].

Fluorescence in situ hybridization (FISH):- is a rapid diagnostic test using molecular cytogenetic techniques. The FISH technique supplements conventional cytogenetic and in some cases provides additional information, which is not detected by karyotyping. A large number of cells can be studied by FISH, since interphase nuclei can also be analyzed [7]. FISH technique performed on interphase cells from both peripheral blood (PB) and bone marrow[8]. This helps in the detection of minimal residual disease, assessment of the rate of cytogenetic remission and detection of disease recurrence [9].

FISH detects BCR-ABL in about $95 \%$ of CML cases. It is the most sensitive test for diagnosis because it detects the approximately $5 \%$ of cases with "masked" translocations that are missed by cytogenetics [10], and it also detects rare cases with variant breakpoints falling outside the regions covered by PCR primers FISH has several advantages over cytogenetic. The specificity of the newer split signal assay is high. Also, unlike cytogenetic, which requires dividing metaphase cells, FISH can be performed on interphase nuclei in peripheral blood. It therefore may bypass the requirement for a bone marrow specimen. However, the percentage of BCR-ABL positive nuclei determined by FISH using peripheral blood specimens 
seems to be lower than that using bone marrow.[11]

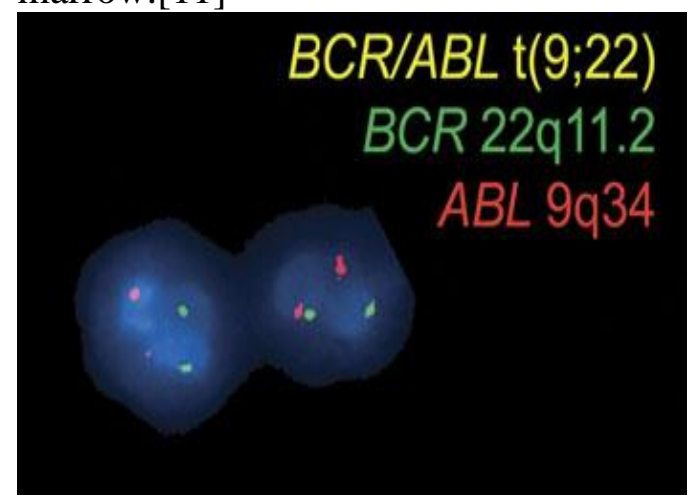

Fig. (1):The FISH strategy to detect the $t(9 ; 22)$ uses 2 differently labeled probes. A normal interphase nucleus (left) reveals 4 separate signals, 2 for each allele of $B C R$ (green) and $A B L$ (red). The appearance of a red-green fusion signal (nucleus to right) indicates the presence of $B C R-A B L$ and is diagnostic of CML (4,6diamidino-2-phenylindoledihydrochloride nuclear counterstain, $\times 100$ ). Courtesy of $A$. Roy, Department of Pathology, Brigham and Women's Hospita

The first tyrosine kinase inhibitor for CML, imatinib mesylate was a major breakthrough in CML treatment, After 6 years of treatment, the overall survival (OS) was $88 \%$ [12]. Resistance to imatinib occurs annually in $3 \%$ to $4 \%$ of patients with CML in chronic phase (CML-CP), and is defined as failure to achieve complete hematologic response (CHR) within 3 months of therapy, any cytogenetic response within 6 months, or major cytogenetic response $\left(\mathrm{Ph}^{+} \leq 35 \%\right)$ within 12 months, or the development of cytogenetic or hematologic relapse [13]. Resistance can be mediated through BCR-ABL-dependent mechanisms, often through mutations in the ABL kinase domain (40\%$50 \%$ ), or by mechanisms independent of BCR-ABL[14]. Nilotinib (Tasigna (B) a second generation TKI derived from imatinib, is a selective Abl inhibitor that binds to the inactive/closed conformation of the Abl kinase that also inhibits c-KIT, ARG, PDGF $\alpha$ and PDGF $\beta$. Nilotinib was approved in 2007 for treatment of CML patients with resistance or intolerance to imatinib and was in 2010 approved for newly diagnosed patients[15] The cumulative rates of MMR (major molecular remission) by 3 years was $70 \%$ to $73 \%$ with nilotinib (two different doses) and 53\% with imatinib, combined with a significantly lower rate of transformation to AP or BP was observed, $2.1-3.2 \%$ vs $6.7 \%$, respectively[16].

Nilotinib can cause several side effects which varies from mild to moderate side effect (QT prolongation, sudden death, myelosuppresion, elevated serum lipase, hepatotoxicity and electrolyte disturbances). The use of Tasigna can cause hypophosphatemia, hypokalemia, hyperkalemia, hypocalcemia, hypercalcaemia, hypomagnesemia, and hyponatremia. Electrolyte abnormalities must be corrected prior to initiating Tasigna and these electrolytes should be monitored periodically during therapy[17].

\section{Subjects, Materials and Methods:-}

This study was conducted between December 2012up to May2013; during this period 30 Iraqi patients of chronic myeloid leukemia treated with imatinb who failed to achieve cytogenetic response for various duration of treatment where the physician decided to go for the second generation of TKI (Nilotinb) were submitted for this study at Baghdad Teaching Hospital/Hematology Department. Laboratory tests including complete blood picture and fluorescent in situ hybridization for BCR-ABL conducted in Lab. Of Hematology and Immunology while the electrolytes 
$\left(\mathrm{Na}^{+}, \mathrm{K}^{+}, \mathrm{Ca}^{++}, \mathrm{PO}_{4}^{---}\right.$and $\left.\mathrm{Mg}^{++}\right)$ conducted in Al-Nadhir Lab. Results were considered in our evaluation before starting treatment with Nilotinb and after two months from the start of the treatment. FISH study done using heprinzied blood samples from the patients pre and after treatment using the interphase FISH technique. Electrolyte assay (potassium and sodium) carried out by using ISE (ion selective electrode), for phosphate, calcium and magnesium the assay done by Cobas C311 chemistry analyzer photometrical measurement, and both instruments ( ISE analyzer and Cobas C311) from Roche.

\section{Result:}

The data obtained from the CML patients before starting treatment with Nilotinib where all of them have no response to Glivec or develop resistance to glivec these results for ( $\mathrm{Ca}, \mathrm{Na}, \mathrm{K}, \mathrm{Mg}$ and $\mathrm{PO}_{4}$ in addition to FISH study results) compared once with control healthy group and another time compared with the results of the same patients after starting the treatment with Nilotinib.

Table (1) FISH results statistics for pre and post treatment

\begin{tabular}{|l|l|l|l|l|l|l|l|l|l|}
\hline & \multicolumn{4}{|c|}{ Pre treatment } & \multicolumn{4}{c|}{ After treatment } & \multirow{2}{*}{ P value } \\
\hline & Mean & $\mathrm{N}$ & \pm SD & Median & Mean & $\mathrm{N}$ & \pm SD & Median & \\
\hline FISH & $58.7 \%$ & 30 & $26.2 \%$ & $62.0 \%$ & $45.7 \%$ & 30 & $29.9 \%$ & $5.56 \%$ & .000 \\
\hline
\end{tabular}

Table (2) The tabel shows the mean,SD,median, and $P$ value for $\left(\mathrm{Ca}, \mathrm{Na}, \mathrm{K}, \mathrm{Mg}, \mathrm{PO}_{4}\right)$ befor treatment compared with healthy control group.

\begin{tabular}{|c|c|c|c|c|c|c|c|c|c|}
\hline & \multicolumn{4}{|c|}{ Pre treatment } & \multicolumn{4}{|c|}{ Control group } & P value \\
\hline & Mean & $\mathrm{N}$ & $\pm \mathrm{SD}$ & Median & Mean & $\mathrm{N}$ & \pm SD & Median & \\
\hline $\mathrm{Ca}^{++}(\mathrm{mg} / \mathrm{dL})$ & 8.69 & 30 & 1.68 & 8.81 & 9.12 & 30 & .38 & 8.97 & .223 \\
\hline $\mathrm{PO}_{4}^{-\cdots}(\mathrm{mg} / \mathrm{dL})$ & 2.51 & 30 & .84 & 2.40 & 3.43 & 30 & .49 & 3.44 & .001 \\
\hline $\mathrm{Na}^{+}(\mathrm{mmol} / \mathrm{L})$ & 139.21 & 30 & 6.91 & 139.00 & 140.42 & 30 & 2.51 & 140.50 & .420 \\
\hline $\mathbf{K}^{+} \quad(\mathrm{mmol} / \mathrm{L})$ & 4.63 & 30 & .70 & 4.50 & 4.46 & 30 & .76 & 4.30 & .393 \\
\hline $\mathrm{Mg}^{++}(\mathrm{mg} / \mathrm{dL})$ & 1.93 & 30 & .342 & 1.95 & 2.10 & 30 & .342 & 2.01 & .017 \\
\hline
\end{tabular}

Table (3) The tabel shows the mean,SD,median, and $P$ value for $\left(\mathrm{Ca}, \mathrm{Na}, \mathrm{K}, \mathrm{Mg}, \mathrm{PO}_{4}\right)$ after treatment compared with healthy control group.

\begin{tabular}{|c|c|c|c|c|c|c|c|c|c|}
\hline & \multicolumn{4}{|c|}{ After treatment } & \multicolumn{4}{|c|}{ Control group } & P value \\
\hline & Mean & $\mathrm{N}$ & $\pm \mathrm{SD}$ & Median & Mean & $\mathrm{N}$ & $\pm \mathrm{SD}$ & Median & \\
\hline $\mathrm{Ca}^{++}(\mathrm{mg} / \mathrm{dL})$ & 8.1 & 30 & 1.72 & 8.8100 & 9.12 & 30 & 0.38 & 8.975 & 0.004 \\
\hline $\mathrm{PO}_{4}{ }^{---}(\mathrm{mg} / \mathrm{dL})$ & 2.95 & 30 & 1.04 & 2.4 & 3.43 & 30 & 0.49 & 3.4 & 0.033 \\
\hline $\mathrm{Na}^{+}(\mathrm{mmol} / \mathrm{L})$ & 142.41 & 30 & 9.24 & 140.0 & 140.42 & 30 & 2.52 & 140.5 & 0.273 \\
\hline $\mathrm{K}^{+}(\mathrm{mmol} / \mathrm{L})$ & 4.33 & 30 & 0.68 & 4.3 & 4.46 & 30 & 0.76 & 4.3 & 0.539 \\
\hline $\mathrm{Mg}^{++}(\mathrm{mg} / \mathrm{dL})$ & 2.07 & 30 & 0.45 & 1.95 & 2.11 & 30 & 0.1 & 2.01 & 0.634 \\
\hline
\end{tabular}

Table (4) The tabel shows the mean, SD, median, and $\mathrm{P}$ value for (Ca, $\mathrm{Na}, \mathrm{K}, \mathrm{Mg}$, $\mathrm{PO}_{4}$ ) pretreatment compared with post treatment.

\begin{tabular}{|c|c|c|c|c|c|c|c|c|c|}
\hline & \multicolumn{4}{|c|}{ Pre treatment } & \multicolumn{4}{|c|}{ After treatment } & \multirow{2}{*}{$P$ value } \\
\hline & Mean & $\mathrm{N}$ & $\pm \mathrm{SD}$ & Median & Mean & $\mathrm{N}$ & $\pm \mathrm{SD}$ & Median & \\
\hline $\mathrm{Ca}^{++}$(mg/dL) & 8.69 & 30 & 1.68542 & 8.8100 & 8.10 & 30 & 1.72257 & 8.5900 & .156 \\
\hline $\mathrm{PO}_{4}^{-\cdots}(\mathrm{mg} / \mathrm{dL})$ & 2.51 & 30 & .83698 & 2.4000 & 2.95 & 30 & 1.04223 & 2.7600 & .018 \\
\hline $\mathrm{Na}^{+}(\mathrm{mmol} / \mathrm{L})$ & 139.21 & 30 & 6.910 & 139.00 & 142.41 & 30 & 9.241 & 140.00 & .144 \\
\hline $\mathrm{K}^{+}(\mathrm{mmol} / \mathrm{L})$ & 4.63 & 30 & .6980 & 4.500 & 4.33 & 30 & .6810 & 4.300 & .092 \\
\hline $\mathrm{Mg}^{++}(\mathrm{mg} / \mathrm{dL})$ & 1.93 & 30 & .34240 & 1.9500 & 2.07 & 30 & .44564 & 1.8000 & .183 \\
\hline
\end{tabular}




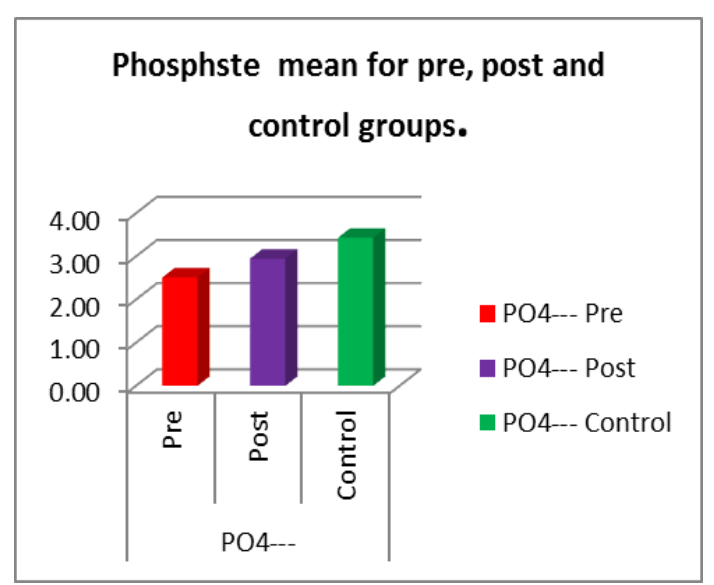

Fig. (2)

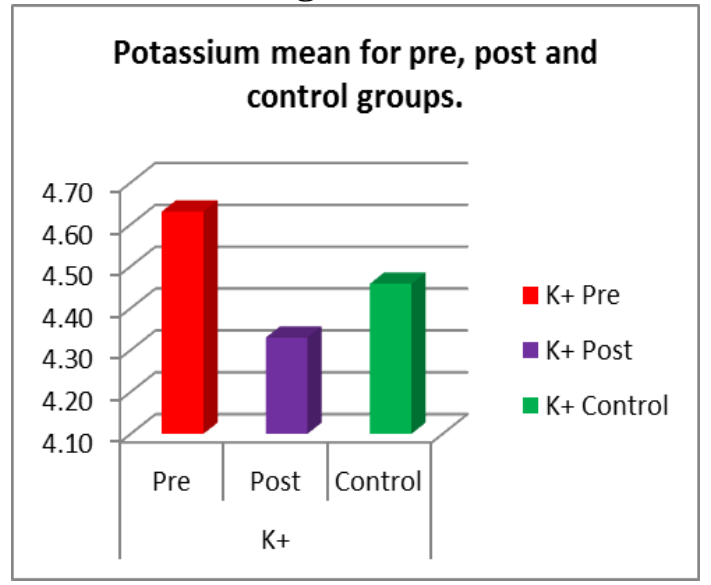

Fig. (4)
Magnesium mean for pre, post and control groups.

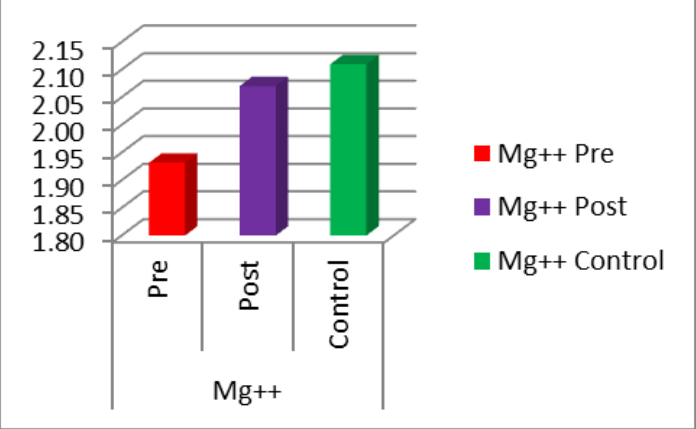

Fig.(3)

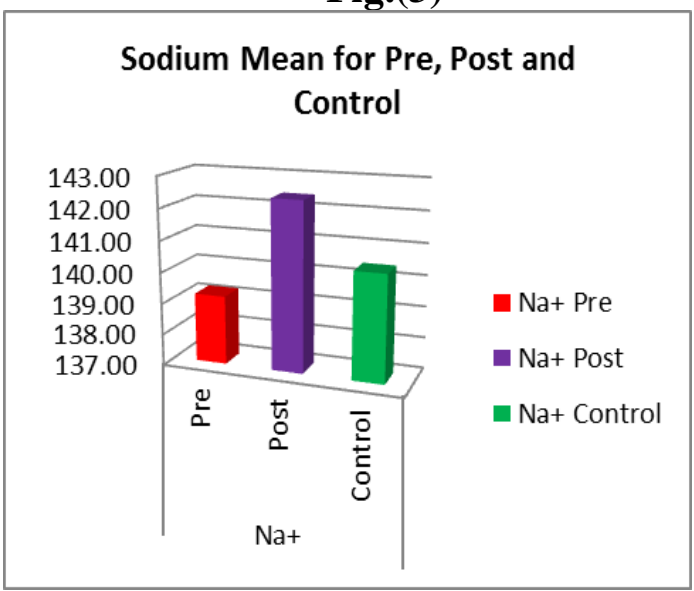

Fig. (5)

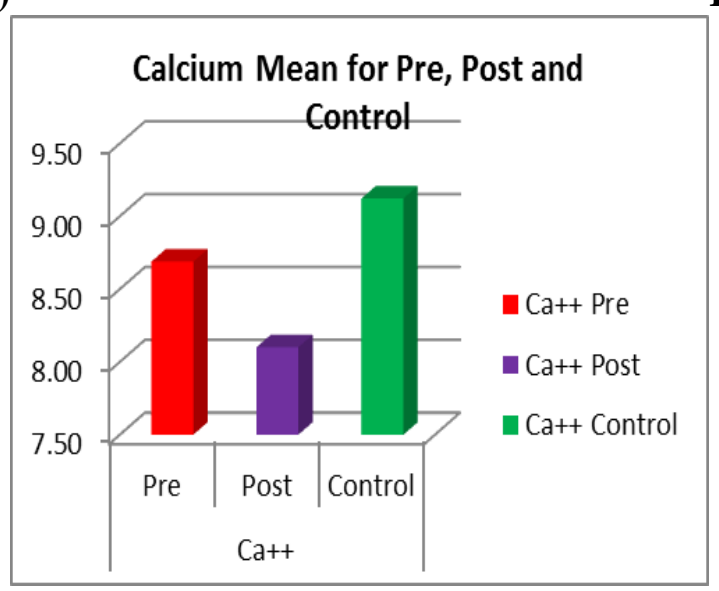

Fig. (6)

Figures above $(2,3,4,5$ and 6$)$ represent the pre, Post treatment and control Mean levels comparison for $\mathrm{Po}^{---}, \mathrm{Mg}^{++}, \mathrm{K}^{+}, \mathrm{Na}^{+} \& \mathrm{Ca}^{++}$respectively.

\section{Discussion:}

FISH results comparison between pre and post treatment group showed significant decrease in BCR- ABL carrying cells percentage which agrees with studies of Mauro(2009)[18] study, Hazarika and Kantarjian studies(2008)[19,20], taking in consideration the interval between pre and post treatment sampling where in the mentioned studies 6 months while in this study it was 1-3 months.

Regarding Sodium, Potassium and Magnesium there was no significant difference in all comparisons between pre, post and control groups which also 
agrees with the studies of Nilotinib prescribing information and with Hughes TP, et al.(2012)[21] study, although more patients enrolled in the previous studies ( more than 100 ) but the results of this study agree with the previous two studies.

Phosphate results for pre, post and control groups shows significant difference in phosphate levels for all comparisons where there was significant decrease of phosphate levels for both pre and post treatment groups in comparison with control group, there was also significant difference between pre and post treatment group where the last one shows higher levels which can be attributed to previous effect of Glivec at these patients because Imatinib has more adverse effect on phosphate and calcium because it had been observed to cause hypophosphatemia and hypocalcemia due to altered bone and mineral metabolism.[22,23,24,25]

These results for phosphate level also agree with ENEST trial study (2012)[26] and with Hughes TP, et al.(2012) study showed that the number was more than of patients who have hypophosphatemia in Imatinib group which is opposite to pretreatment group in this study in comparison with patients receiving Nilotinib which agrees with our results. Regarding Calcium there was no significant difference in all comparison except for that between post treatment group and control, agreed with Tasigan prescribing information by (Novartis ) that was in two different studies $321 \mathrm{CML}$ patients who were enrolled in one study and $137 \mathrm{CML}$ patients who were in another study whose percent of hypocalcemia was 2 and $5 \%$ respectively[26].

\section{Conclusion:}

This study sheds a light on the molecular cytogenetic response for CML patients who have already resistance to Imatinib and Nilotinib that has much more potent effect as approved by studies and this study has used FISH technique.

This study emphasizes on the importance of evaluation of electrolyte panel for CML patients before starting Nilotinib study taking in to consideration if these patients are already receiving Imatinib which can also affect bone metabolism and calcium and phosphate levels.

\section{References:}

1- Swerdlow SH, et al (ed.) 2008. WHO Classification of tumors of hematopoietic and lymophoid tissues, Lyon, France: IARC.

2- Rowley JD. 1973. A new consistent chromosomal abnormality in chronic myelogenous leukaemia identified by quinacrine $\mathrm{f}$ luorescence and Giemsa staining. Nature; 243:2903.

3- Vardiman J, Harris N, Brunning R 2002. "The World Health Organization (WHO) classification of the myeloid neoplasms".

4- Jabbour E, Cortes JE, Giles FJ, et al. 2007. Current and emerging treatment options in chronic myeloid leukemia. Cancer; 109(11):2171-2181.

5- Charles L.Sawyers, M.D.,( April 29, 1999. Review Article, Nejm volume 340 No. 17.

6- Kantarjian H, Shah NP, Hochhaus A, et al. 2010. Dasatinib versus imatinib in newly diagnosed chronic-phase chronic myeloid leukemia. $\quad N \quad$ Engl J Med.;362(24):2260-2270.

7- Jadayel D, Calabrese G, Min T, van Rhee F, Swansbury GJ,Dyer MJ, Maitland J, Palka G, Catovsky 
D. 1995. Molecular cytogenetics of chronic myeloid leukaemia with atypical $\mathrm{t}(6 ; 9)(\mathrm{p} 23 ; \mathrm{q} 34)$ translocation. Leukaemia 9:981.

8- Hochhaus A, Reither A, Skladny $\mathrm{H}$, et al.1996. A novel BCR-ABL fusion gene (e6a2) in a patient with Philadelphia chromosomenegative chronic myelogenous leukemia. Blood 88:2236.

9- Cuneo A, Bigoni R, Emmanuel B, Smit E, Rigolin GM, Roberti MG, Bardi A, Piva N, Scapoli G, Castoldi G, Van Den Berghe H,Hagemeijer A. 1998. Fluorescence in situ hybridization for the detection and monitoring of the Ph-positive clone in chronic myelogenous leukemia: comparison with metaphase bandinganalysis. Leukemia 12:1718-1723.

10-Buno I, Wyatt WA, Zinsmeister AR, Dietz-Band J, Silver RT, Dewald GW. 1998. A special fluorescent in situ hybridizationtechnique to study peripheral blood and assess the effectiveness of interferon therapy in chronic myeloid leukemia. Blood 92: 2315-2

11-Landstrom AP, Ketterling RP, Knudson RA, et al. 2006. Utility of peripheral blood dual color, double fusion fluorescent in situ hybridization for BCR/ABL fusion to assess cytogenetic remission status in chronic myeloid leukemia. Leukemia \& lymphoma 47:2055-61.

12- Allan NC, Richards SM, Shepherd PC. 1995. UK Medical Research Council randomised, multicentre trial of interferon-alpha $\mathrm{n} 1$ for chronic myeloid leukaemia: improved survival irrespective of cytogenetic response. The UK Medical Research Council's Working Parties for Therapeutic
Trials in Adult Leukaemia. Lancet 345:1392-7.

13- Hantschel O, Rix U, Superti-Furga G. 2008. Target spectrum of the BCR-ABL inhibitors imatinib, nilotinib and dasatinib. Leukemia \& lymphoma 49:615-9.

14- Deremer DL, Ustun C, Natarajan K. 2008. Nilotinib: a secondgeneration tyrosine kinase inhibitor for the treatment of chronic myelogenous leukemia. Clinical therapeutics 30:1956-75.

15- Larson RA, Hochhaus A, Hughes TP, et al. 2012. Nilotinib vs imatinib in patients with newly diagnosed Philadelphia chromosome-positive chronic myeloid leukemia in chronic phase: ENESTnd 3-year followup. Leukemia : official journal of the Leukemia Society of America, Leukemia Research Fund, U.K 26:2302.

16- Kantarjian H. 2012. Enestnd 4Year (y) Update: Continued Superiority of Nilotinib Vs Imatinib in Patients (pts) with Newly Diagnosed Philadelphia Chromosome-Positive (Ph+) Chronic Myeloid Leukemia in Chronic Phase (CML-CP). Atlanta.

17- K. Leigh McFarland, PharmD, and Gene A. Wetzstein, PharmD, BCOP. 2010. Chronic Myeloid Leukemia Therapy: Focus on Second-Generation Tyrosine Kinase Inhibitor.Cancer Control J. 137-138; Vol. 16 No. 2.

18- Mauro MJ, Deininger MW. 2009. Management of drug toxicities in chronic myeloid leukaemia. Best practice \& research. Clinical haematology 22:409-29.

19- Hazarika M, Jiang X, Liu Q et al .2008.Tasigna for chronic and accelerated phase Philadelphia chromosome-positive chronic myelogenous leukemia resistant to 
or intolerant of imatinib. Clin Cancer Res 14:5325-5331.

20- Jabbour E, Kantarjian H, jones D et al .2008b. Characteristics and outcome of patients with chronic myeloid leukemia and T315I mutation following failure of imatinib mesylate therypy. Blood 112:53-55.

21- Hughes TP, Lipton JH, Spector N, et al. Switching to Nilotinib Is Associated with Continued Deeper Molecular Responses in CML-CP Patients with Minimal Residual Disease After 2 Years On Imatinib: Enestcmr 2-Year Follow-up Results. Blood (ASH Annual Meeting Abstracts) 2012 120: Abstract 694.

22- Daniel B. Petrov, M.D. October 4, 2012. Hyperkalemia in Renal Insufficiency, at NEJM.org.

23- Dominique Prié, M.D., Ph.D., and Gérard Friedlander, M.D., Ph.D.
2010. Genetic Disorders of Renal Phosphate Transport, $N$ Engl J Med;362:2399-409.

24-Favus MJ, ed. 2003. Primer on the metabolic bone disease and disorders of mineral metabolism, 5th ed. Washington DC: American Society for Bone and Mineral Research.

25-Ellin Berman, M.D., Maria Nicolaides, M.D., et al. 2006. Altered Bone and Mineral Metabolism in Patients Receiving Imatinib Mesylate., $N$ Engl.J Med;354:2006-13m.

26- Kantarjian H. 2012. Enestnd 4Year (y) Update: Continued Superiority of Nilotinib Vs Imatinib in Patients (pts) with Newly Diagnosed Philadelphia Chromosome-Positive $(\mathrm{Ph}+)$ Chronic Myeloid Leukemia in Chronic Phase (CML-CP). Atlanta. 


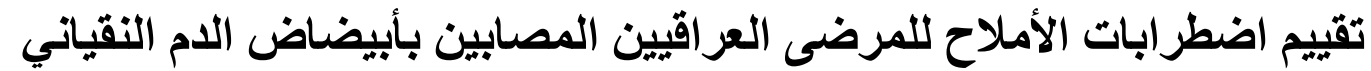

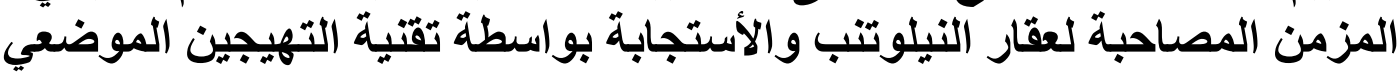 الوامض والو}

رسل بعرب حمبإث*

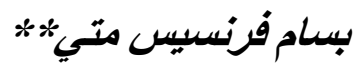

بشرى فارس حسن

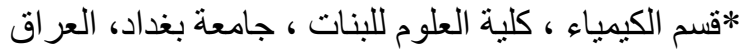

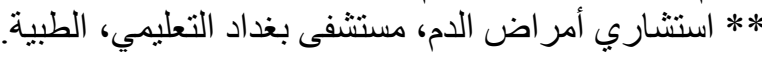

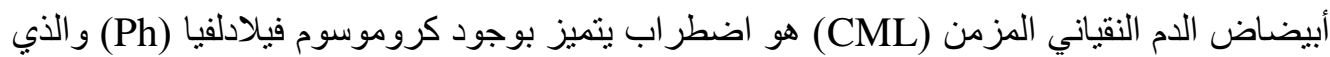

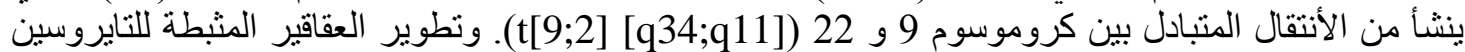

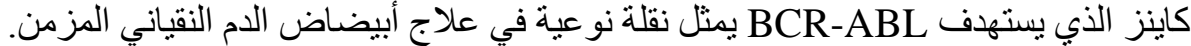

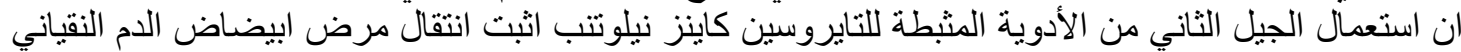

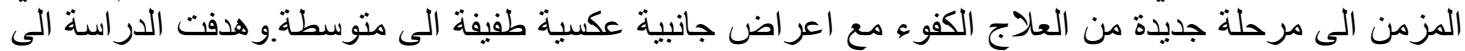

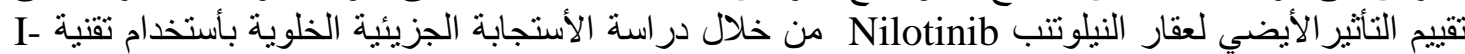

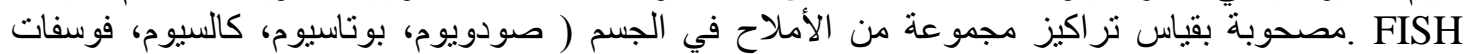

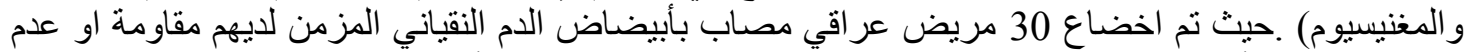

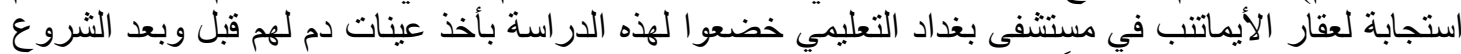

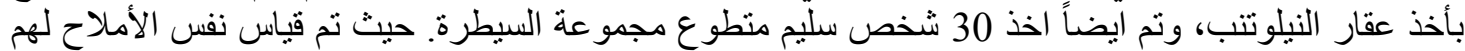

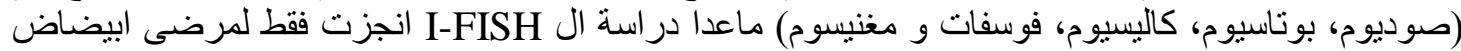

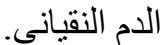
حيث اظهرتث النتائج من اصل ثلاثون مريضاً عراقياً هناك (17 ذكور و13 اناث)، نسبة الذكر الى الأنثى

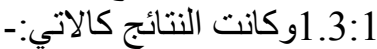

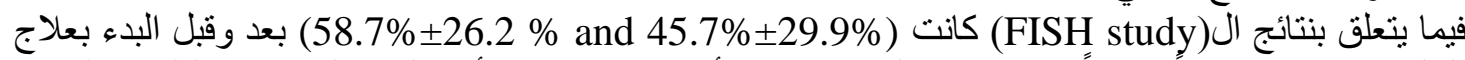

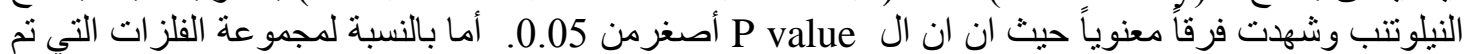

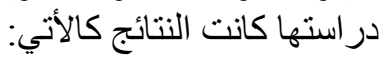

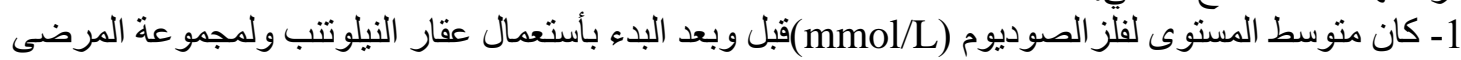

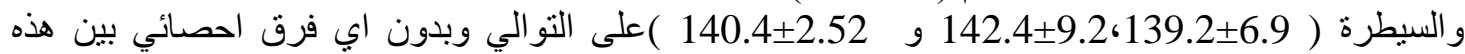

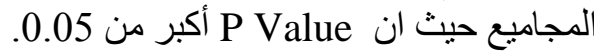

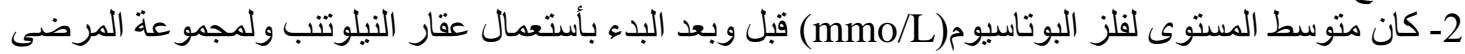

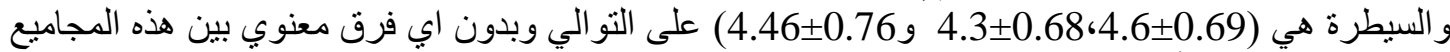

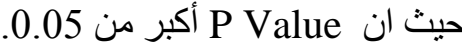

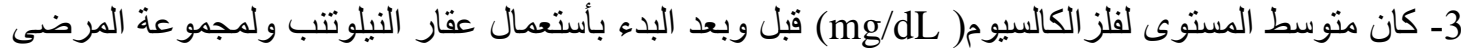

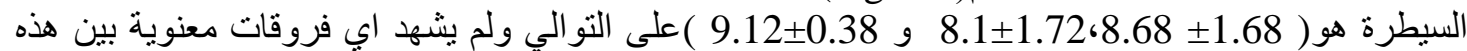

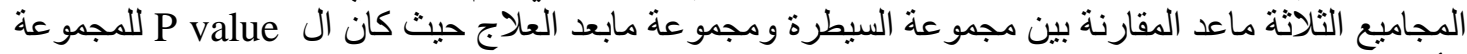

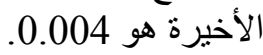
4- كان منوسط المستوى لفلز الفوسفات (

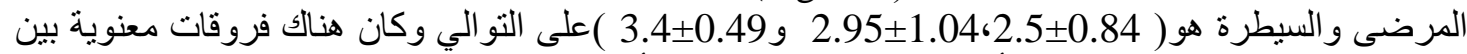

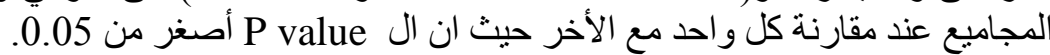

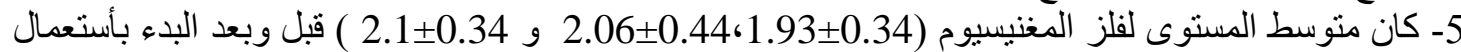

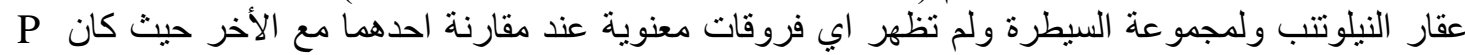
. value

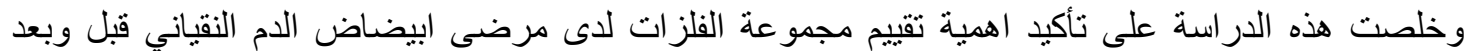

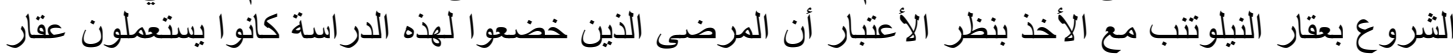

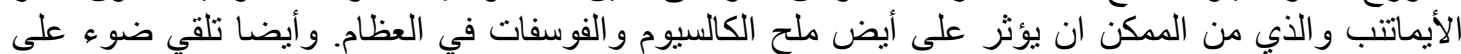

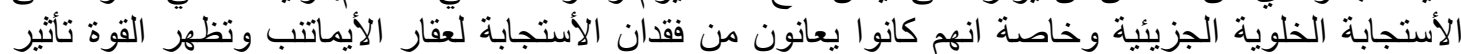

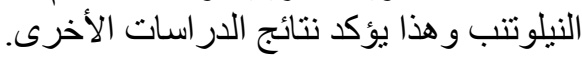

